\title{
A LINGUAGEM PUBLICITÁRIA NA SUSTENTABILIDADE AMBIENTAL
}

\author{
GIOVANA GORETTI FEIJÓ DE ALMEIDA \\ UNIVERSIDADE DE SANTA CRUZ DO SUL \\ SANTA CRUZ DO SUL, RIO GRANDE DO SUL, BRASIL \\ GORETTI.GIOVANA@GMAIL.COM
}

HTTP://DX.DOI.ORG/10.5902/2316882X21399 


\section{A LINGUAGEM PUBLICITÁRIA NA SUSTENTABILIDADE AMBIENTAL}

Resumo: O objetivo é o de discutir sobre o uso da linguagem publicitária, na perspectiva da sustentabilidade ambiental, colocando a publicidade como prática e como produto que põe em circulação múltiplos significados. Foram analisados anúncios publicitários que utilizam a sustentabilidade ambiental em seus conteúdos como argumento publicitário. Os resultados apontam para a importância da responsabilidade das empresas em fazerem ações publicitárias.

Palavras-chave: Publicidade. Discurso publicitário. Sustentabilidade Ambiental.

\section{PUBLICIDAD DE IDIOMAS EN LA SOSTENIBILIDAD AMBIENTAL}

Resumen: El objetivo es discutir el uso de lenguaje publicitario desde el punto de vista de la sostenibilidad ambiental, la colocación de la publicidad como práctica y como un producto que pone en circulación múltiples significados. anuncios fueron analizados utilizando la sostenibilidad del medio ambiente en su contenido como argumento publicitario. Los resultados apuntan a la importancia de la responsabilidad corporativa en la toma de acciones publicitarias.

Palabras clave: Publicidad. Discursos publicidad. Sostenibilidad ambiental.

\section{LANGUAGE ADVERTISING IN THE ENVIRONMENTAL SUSTAINABILITY}

Abstract: The goal is to discuss the use of advertising language from the perspective of environmental sustainability, placing advertising as a practice and as a product that puts into circulation multiple meanings. advertisements were analyzed using environmental sustainability in their content as an advertising argument. The results point to the importance of corporate responsibility in making advertising actions.

Key words: Advertising. Speeches advertising. Environmental sustainability. 


\section{INTRODUÇÃO}

O ser humano vive em uma sociedade na qual o consumo ocupa um grande espaço. Já não é mais possível pensar em empresas ou ações que não sejam sustentáveis. Dessa forma, o tema sustentabilidade tem tido grande relevância. Mas o que é sustentabilidade? Esse conceito é entendido da mesma forma tanto por estudiosos quanto por empresários? As respostas para essas questões são imprescindíveis para que haja sintonia entre estudos e ações, principalmente as ações empresariais.

Muitas organizações acreditam que o simples fato de usarem os dois lados de uma mesma folha de papel em seus processos já é uma medida que as torna "ecologicamente corretas", passando a se auto intitularem "sustentáveis ambientalmente". A definição de sustentabilidade é bastante ampla e precisa ser analisada profundamente para que seja compreendida por todos os envolvidos em sua proposta. Caso contrário, seu significado tenderá a ser interpretado e aplicado de forma equivocada. Nesse contexto de melhorar a qualidade de vida das pessoas, a sustentabilidade ambiental tem um papel essencial (SOUZA e AWAD, 2012)

Neste sentido, este artigo pretende refletir sobre a ideia da sustentabilidade ambiental na composição do discurso persuasivo da publicidade. É feita, portanto, uma discussão da publicidade sob o ponto de vista da sustentabilidade. A linguagem publicitária emprega frases de efeito, metáforas, palavras de duplo sentido, simbolismos e jogos de imagens para gerar uma comunicação estratégica que influencia a decisão de compra das pessoas (RANDAZZO, 1997; JONES, 2004; BAUDRILHARD, 2008). Se esta não for empregada da forma correta, poderá induzir o público ao erro e a receber informações não verdadeiras. É preciso ter responsabilidade com o uso do discurso publicitário e sua linguagem (emissor), sob o risco de o receptor da mensagem (consumidor) não compreendê-la totalmente, perdendo-se a garantia da ausência do chamado ruído na comunicação transmitida.

Entretanto, a sustentabilidade utilizada como subproduto da publicidade nem sempre tem como se ancorar na veracidade das informações que comunica. Ela pode se manter por um tempo curto e até mesmo vender o produto por ter em sua "essência" a sustentabilidade. Contudo, como se verá mais adiante, a sustentabilidade é um tema bem amplo, muito mais do que apenas um argumento mercadológico de venda de produtos. As

Rev.Cad. Comun. Santa Maria, v.21, n.1, art 3, p.61 de 85, jan/abr.2017 
questões acima colocadas levam à reflexão sobre a utilização da publicidade como ferramenta no processo de construção da imagem socioambiental e sustentável de uma empresa e sua marca. Pode-se perguntar se é importante para uma organização comunicar uma ação sustentável? A resposta é sim, desde que esta informe o que, de fato, está realizando.

Para alcançar os objetivos propostos neste artigo a metodologia empregada foi a de natureza qualitativa, de cunho exploratório. O levantamento de dados foi feito a partir de uma escolha aleatória de oito anúncios publicitários feitos por construtoras, incorporadoras ou imobiliárias brasileiras, coletados via internet, que vendem seus imóveis usando o contexto da sustentabilidade, direta ou indiretamente, em seus layouts como argumento de venda. A análise do material foi feita a partir da linguagem publicitária, comparando os elementos encontrados em cada anúncio e no conjunto dos anúncios coletados. Sendo assim, a análise concentrou-se em dois tipos: 1) análise verbal e, 2) análise não verbal.

No primeiro tipo foram considerados tudo que está escrito no anúncio: título (chamada principal), subtítulo, texto informativo, nome do empreendimento e duplo sentido do texto. Já no segundo tipo, a análise foca sua atenção no visual dos anúncios: cores, formas como foi escrito o título e imagens utilizadas. Dessa forma, pode-se fazer uma reflexão mais aprofundada. Como o intuito neste artigo é refletir sobre a sustentabilidade ambiental analisando anúncios publicitários, retirou-se o nome das construtoras, incorporadoras e imobiliárias do material, preservando o restante do anúncio.

\section{A SUSTENTABILIDADE AMBIENTAL NA CONTEMPORANEIDADE}

Ser sustentável não é apenas cuidar da natureza, mas ser responsável por tudo, inclusive com as cidades, que também fazem parte da natureza na contemporaneidade. Não se pode separar uma da outra no sentido de cuidar apenas da natureza ou apenas da cidade. Quanto mais as cidades crescem, mais provocam mudanças (em termos de estrutura, mobilidade urbana, qualidade de vida, necessidades básicas, entre outras) em tudo à sua volta, agravando os problemas ambientais, levando o homem a se preocupar com a forma de vida que leva e, portanto, a modificar seus hábitos cotidianos. De acordo com Kato (2007, p. 8) essa pressão populacional concentrada nas cidades e na busca desenfreada pelo desenvolvimento

Rev.Cad. Comun. Santa Maria, v.21, n.1, art 3, p.62 de 85, jan/abr.2017 
proporcionado pelas novas tecnologias, principalmente às voltadas ao consumo, ocasionaram diversos danos ao planeta (água, energia, alimentos, construção civil que utiliza recursos naturais, etc). Torna-se fundamental reverter esse panorama ambiental negativo, a fim de preservar a vida do próprio ser humano. Enfim, é preciso rever a forma como a sociedade tem se desenvolvido e como pretende se desenvolver, levando em conta a dinâmica urbana. Segundo Anne Spirn (1995) citada por Bemfica e Bemfica (2014, p. 2),

a natureza na cidade é muito mais do que árvores e jardins e ervas nas frestas das calçadas e nos terrenos baldios. [...] é a consequência de uma complexa interação entre os múltiplos propósitos e atividades dos seres humanos e de outras criaturas vivas e dos processos naturais que governam a transferência de energia, o movimento do ar, a erosão da terra e o ciclo hidrológico. A cidade é parte da natureza.

O mundo se urbanizou a tal ponto que é preciso considerar as cidades dentro do contexto da sustentabilidade ambiental. Para Souza e Awad (2012, p. 14) "as cidades devem ser vistas como oportunidades e não como problema. [...] As cidades se reinventam." Nessa reinvenção urbana a partir dos problemas gerados pelas cidades, são elas as responsáveis pelas respostas. Contudo, para que as cidades possam ver oportunidades em seus problemas, é preciso entendê-los e deixar claro quais são eles para que não restem dúvidas quanto à necessidade de soluções. Um desses entendimentos é sobre a essência da sustentabilidade e seus segmentos.

Portanto, para conceitualizar a sustentabilidade ambiental, é preciso, primeiramente, entender o conceito de sustentabilidade. A globalização trouxe o tema sustentabilidade também para as cidades. No entanto, é ainda um conceito com diferentes compreensões. De acordo com o Relatório de Desenvolvimento Humano, do Programa das Nações Unidas para o Desenvolvimento, "a sustentabilidade está irremediavelmente ligada às questões básicas de igualdade - ou seja, equidade, justiça social e maior acesso a uma melhor qualidade de vida" (PNUD, 2011). Essa qualidade de vida pressupõe um mundo melhor e mais justo para se viver, assim como, um consumo mais consciente, já que por muito tempo as questões ambientais foram deixadas de lado, conforme salientado por Kato (2008), privilegiando apenas o desenvolvimento econômico sem se importar com o tipo de indústrias que estariam sendo instaladas no território brasileiro.

Rev.Cad. Comun. Santa Maria, v.21, n.1, art 3, p.63 de 85, jan/abr.2017 
Assim, se torna imprescindível à sociedade refletir sobre que tipo de desenvolvimento tem investido ao longo do tempo e qual desenvolvimento irá manter em um futuro próximo.

A Conferência das Nações Unidas sobre o Desenvolvimento Sustentável (RIO+20, 2012), focou suas discussões em dois temas centrais: 1) como construir uma economia verde para alcançar o desenvolvimento sustentável e retirar as pessoas da pobreza; e, b) como melhorar a coordenação internacional para o desenvolvimento sustentável. Cada governo analisa sua situação e adota as medidas necessárias para atingir suas metas. Essas escolhas governamentais são focadas, portanto, em práticas para a implementação do desenvolvimento sustentável. De acordo com a referida Conferência, desenvolvimento sustentável é "o desenvolvimento que atende às necessidades do presente sem comprometer a capacidade das gerações futuras de atender suas próprias necessidades.". É, portanto, a garantia de desenvolvimento sem que haja agressão ao meio ambiente, garantindo, assim, que os recursos naturais, necessários para a qualidade de vida das próximas gerações, estejam disponíveis no futuro.

Sustentabilidade, na visão de Rosa (2007), é também uma forma da sociedade questionar o tipo de desenvolvimento que mantém. Um modelo que se mostra inadequado à realidade contemporânea, fazendo-se necessário repensar a sociedade industrial que se pretende ter em um futuro próximo. A sustentabilidade ambiental é um conceito que se origina da ecologia e tem vários exemplos bem-sucedidos nas áreas como energia, agricultura, produção, consumo e planejamento urbano. Além das medidas dos governos, ações simples como coleta seletiva do lixo e preservação de áreas verdes nas cidades também contribuem para o desenvolvimento sustentável. Entretanto, ainda é essencial o envolvimento de todos: pessoas, grupos comunitários, ONGs, empresários, estudantes, organizações e não apenas um ou outro ator social. Essa é uma meta que deveria e deve envolver todas as pessoas do mundo e não pode ser negligenciada. Quando se fala em sustentabilidade ambiental é preciso refletir sobre a dinâmica do espaço urbano, ou seja, o contexto da sustentabilidade nas cidades.

Dessa preocupação global, surgiram as cidades sustentáveis. Segundo Souza e Awad (2012), são aquelas que adotam uma série de práticas eficientes voltadas para a melhoria da qualidade de vida da população, desenvolvimento econômico, preservação do meio ambiente, planejamento

Rev.Cad. Comun. Santa Maria, v.21, n.1, art 3, p.64 de 85, jan/abr.2017 
focado em bens e serviços, informação e conhecimento, capital e pessoas. Quando o assunto são cidades sustentáveis, há várias questões a serem abordadas além da questão ambiental. É preciso se preocupar com moradia, com o saneamento, inclusão, segurança, mobilidade, oportunidades e a forma de governar que também permeiam pela sustentabilidade do meio ambiente, pois cada vez mais, se percebe que o mundo está se urbanizando.

Algumas das práticas adotadas pelas cidades sustentáveis, citados por Souza e Awad (2012) são: ações efetivas que visam o combate ao aquecimento global; manutenção dos bens naturais comuns; planejamento e qualidade nos serviços de transporte público, principalmente utilizando fontes de energia limpa; ações para melhorar a mobilidade urbana; destino adequado para o lixo; sistemas eficientes de reciclagem de lixo; investimentos em educação de qualidade; planejamento de uma economia local dinâmica e sustentável; adoção de práticas voltadas para o consumo consciente da população; ações que visem o uso racional da água e seu reaproveitamento; programas que visem à melhoria da saúde da população; criação de espaços verdes (parques, praças) voltados para o lazer da população e programas voltados para a arborização das ruas e espaços públicos. Nesse contexto, uma cidade sustentável é muito mais do que apenas preservar áreas verdes.

É oportuno nos debruçarmos sobre a grande questão do século: o planeta urbano. Afinal, se o século 19 foi dos impérios e o 20, das nações, este é o das cidades. E as imensas inovações que ora se anunciam ocorrerão no território urbano (SOUZA e AWAD, 2012, p. 4).

Quando o assunto é sustentabilidade, surgem muitas dúvidas, inclusive no âmbito empresarial. Algumas delas têm relação com o cenário competitivo das organizações, ou seja, a sustentabilidade poderá ameaçar a sobrevivência das organizações? Como as empresas estão se movimentando para se adequarem à nova realidade sustentável? O que é ser realmente um negócio sustentável e manter a competitividade no mercado? Essas são apenas algumas das questões que estão no entremeio do mundo corporativo. No entanto, essa preocupação com a sustentabilidade ainda não é uma prática cotidiana da maioria das organizações. Não parte das corporações a atitude de terem o pensamento voltado à sustentabilidade

Rev.Cad. Comun. Santa Maria, v.21, n.1, art 3, p.65 de 85, jan/abr.2017 
ambiental, focando suas ações nesse objetivo. O grande impulsionador dessa sustentabilidade "forçada" são os aspectos legais relacionados à legislação definida por governos de todos os níveis (municipal, estadual e federal).

As empresas ainda têm dificuldade para entender claramente o que são ações de sustentabilidade. Uma coisa é preservar o planeta, outra é garantir a continuidade do negócio. O que a maior parte das empresas acredita serem ações sustentáveis para o planeta, na verdade, são ações de sustentabilidade do negócio. Do ponto de vista estratégico, as empresas buscam um diferencial competitivo no mercado e encontram na sustentabilidade ambiental essa vantagem que precisa ser comunicada ao público-alvo, consumidor dos produtos e marcas das empresas. E para isso utilizam a publicidade e todo seu arsenal estratégico. Contudo, se torna fundamental comunicar se a empresa está realizando de fato ação de sustentabilidade ambiental ou de sustentabilidade do próprio negócio.

\section{PUBLICIDADE: O CANAL ESTRATÉGICO DAS MARCAS}

A publicidade tornou-se mais do que uma mera ferramenta para venda de produtos, mas em um canal estratégico de comunicação entre marca e consumidor. Casaqui (2009, p. 170) salienta que a publicidade realiza uma mediação que negocia entre um mundo de simbolismos (como o das marcas) e os seus consumidores (mundo real). Nesse sentido, a linguagem publicitária atua como uma força impulsionadora que desperta o desejo de compra das mercadorias, transcendendo o aspecto físico do produto e inserindo-lhe uma aura simbólica de percepção de um novo estilo de vida e comportamento das pessoas.

Essa aura simbólica citada por Casaqui (2009) tem relação com os valores agregados. Jones (2004, p. 21) menciona que esses valores agregados, de cunho psicológico, são "construídos pela experiência do consumidor no uso das marcas [...]”, sendo uma espécie de benefício extra, sendo que esta experiência para ser positiva ou negativa, depende da interação entre consumidor e marca. Tudo acontece na mente. Jones (2004, p.22), ressalta que "na publicidade a intuição e a imaginação exercem um papel real." Por este motivo, tudo que uma marca prometer ao seu público ela deve cumprir, pois, caso contrário, pode gerar uma rejeição significativa das pessoas que interagiram negativamente com ela.

Rev.Cad. Comun. Santa Maria, v.21, n.1, art 3, p.66 de 85, jan/abr.2017 
As pessoas acreditam que os valores simbólicos ajudam na escoIha das marcas. [...] as pessoas acham mais fácil escolher entre produtos que tenham diferenças altamente emocionais do que entre produtos de categorias em que as diferenças são meramente funcionais. [...] A maneira como os significados passam a integrar as marcas é certamente o ponto crucial da questão (JONES, 2004, p. 60-64).

O apelo aos atributos emocionais dos produtos marca mais as pessoas e age dentro da aura simbólica citada por Casaqui (2009) e dos valores agregados mencionados por Jones (2004). É uma interação entre simbolismos, metáforas e valores culturais que comunica uma mensagem publicitária com significados (pré)construídos no intuito de modificar o comportamento ou ações das pessoas. O foco é o imaginário do público e é nesse ponto que o discurso publicitário contribui para a construção das marcas e fluidez de suas mensagens. Randazzo (1997, p. 20) diz que esse tipo de discurso, que tem como base uma linguagem publicitária, "transforma produtos em marcas (...) humanizando-os e dando-lhes identidades precisas, personalidades e sensibilidades que refletem as nossas". As mercadorias deixam de serem coisas e passam a se humanizar, como se fosse alguém conhecido, um amigo ou até mesmo uma pessoa da família. Estas são as sensações que as marcas procuram provocar no público-alvo e em seus consumidores.

Dessa forma, as pessoas veem as marcas como um reflexo de si mesmas ou do que desejariam ser (suas projeções), em uma espécie de projeto de futuro ou do que não são. Para Marcondes (2002, p. 38) a publicidade tem um papel de espelho, "no qual todos nos olhamos e onde temos uma referência aceita e comum de quem somos, [...] o que é moderno e o que não devemos perder de jeito nenhum, sob o risco de ficarmos por fora [...]". Talvez por isso as pessoas comprem marcas que refletem um estilo de vida similar ao seu como os atletas que se identificam com a marca Nike ou Adidas, por exemplo, ou até mesmo os que não possuem o estilo de vida que a marca propõe, mas que gostariam de tê-lo ou até mesmo creem que possuir a marca lhes confere o estilo de vida proposto pelos estrategistas da marca. Percebe-se, portanto, que a publicidade e a linguagem que ela utiliza dentro de um discurso característico têm um papel importante na sociedade de consumo de produtos e serviços e também de seus valores agregados. 


\subsection{A LINGUAGEM PUBLICITÁRIA E A SUSTENTABILIDAdE AM- BIENTAL}

A linguagem publicitária é utilizada para promover a venda de produtos e marcas, criando uma ligação entre o simbólico e a sociedade, entre o imaginário e a realidade. Quando aliada a um discurso publicitário coerente, ela se torna mais persuasiva e também consumista. Baudrillard (2008, p. 180) ressalta que o discurso publicitário tem a capacidade de criar um ambiente peculiar que envolve as pessoas. Nesse sentido, entram os signos, as imagens, a linguagem publicitária (verbal e não verbal), as metáforas, os simbolismos... Tudo colabora na criação do cenário ideal para que o discurso publicitário atinja seus propósitos. Esses elementos são empregados na publicidade como ferramenta no processo de construção das marcas. Atualmente, devido ao tema sustentabilidade estar ganhando notoriedade no mundo todo, eles também são utilizados na elaboração da imagem socioambiental e sustentável das organizações e de seus produtos. É como se a sustentabilidade fosse também uma mercadoria que as marcas inseriram em suas essências.

Trabalhar com a linguagem publicitária pressupõe entender um processo de persuasão que utiliza elementos racionais, emocionais e de convencimento. O primeiro refere-se às características ou atributos do produto em si. O segundo explora as emoções das pessoas. E o último argumento é o misto, ou seja, aquele que sugere no mesmo texto argumentos racionais e emocionais, mesclando um ao outro no intuito de maior persuasão. Todos esses contextos visam à inclusão do público-alvo com a mensagem ofertada, criando um envolvimento das pessoas com o produto ou marca (JONES, 2004). De uma forma mais publicitária, esses elementos persuasivos estão presentes no layout, ou seja, na configuração visual dos anúncios na forma do título, texto, imagens e slogan (promessa de valor da marca). O objetivo de um texto publicitário é sempre o de convencer e persuadir seu público-alvo. Este texto específico, o qual faz parte da publicidade, está no conjunto comunicacional do universo corporativo.

Comunicar-se com os consumidores constitui o objetivo intencional de persuadir o comportamento num sentido determinado e preestabelecido. Cria pelos processos de comunicação um discurso que produz sentido. O consumidor poderá ou não se sentir atraído, quanto mais estiver engendrado em seu cotidiano e identificado com sua cultura, tanto mais ele será percebi-

Rev.Cad. Comun. Santa Maria, v.21, n.1, art 3, p.68 de 85, jan/abr.2017 
do e reconhecido. O discurso publicitário não é um caminho de inspiração divina, é o processo pelo qual o plano estratégico de marketing constituirá a base de operações do composto comunicacional, estabelecendo o conteúdo de comunicação sobre o qual produzirá o sentido pela emissão do discurso publicitário. É fundamental atingir os consumidores sem perder de vista o objetivo estratégico apresentado no conteúdo do discurso emitido pela campanha de publicidade (MUNIZ, 2005).

Para atingir os objetivos propostos em uma campanha publicitária é preciso que a marca conheça seu público-alvo e fale a mesma linguagem, criando, dessa forma, uma sintonia simbólica com valores significativos, gerando certa vantagem competitiva. Observar e compreender o consumidor, assim como acompanhar tudo o que ocorre no mundo é eficaz para se conseguir ter uma sacada que gere um passo à frente da concorrência. Tudo é planejado com o intuito da persuasão, almejando um comportamento ou ação pré-estabelecida.

Contudo, o maior desafio enfrentado pelas empresas atualmente é conseguir criar e agregar mais valor para os consumidores do que seus concorrentes, pois a vantagem competitiva é medida em relação aos concorrentes num mesmo segmento de mercado. Portanto, o valor, a vantagem competitiva e o foco exigido para atingi-los são essenciais e devem orientar os esforços de marketing em qualquer parte do mundo (MUNIZ, 2005).

O cenário empresarial muda com frequência. As empresas, nos últimos anos, estão investindo em outros setores, como o social e o ambiental. A mídia tem mostrado inúmeras campanhas publicitárias com esse enfoque, fazendo com que estas questões sejam ampliadas e se tornem vantagens competitivas para as organizações e suas marcas. Segundo a NeoMundo (2014, p. 35), "a publicidade de hoje transita da valorização do consumo para a valorização das práticas sustentáveis. [...] havendo um abuso no apelo da sustentabilidade e da responsabilidade social na publicidade". Uma coisa é criar uma campanha publicitária com a imagem de sustentabilidade e outra é ser uma empresa que possui um modelo de gestão sustentável na qual se reflete os valores de sua marca. Nesta, a sustentabilidade faz parte da essência da marca e da própria empresa. Na primeira é apenas propaganda, ou seja, a empresa não é de fato uma organização sustentável ambientalmente.

Rev.Cad. Comun. Santa Maria, v.21, n.1, art 3, p.69 de 85, jan/abr.2017 
Observa-se que há várias interpretações sobre o conceito de sustentabilidade e responsabilidade ambiental. E isso dificulta a transparência de empresas e marcas que realmente se associam a estas causas. Não é a primeira vez que surgem essas confusões conceituais. Até hoje se confunde marketing social com ações de filantropia, por exemplo. Fazer doações, coletas de lixo ou plantar árvores não é necessariamente ter responsabilidade social ou ter sustentabilidade ambiental. Essas são gestões estratégicas das empresas que são mais do que apenas imagens externas. Tem a ver com a missão, visão e valores verdadeiros das organizações. Valores esses que são mais endógenos do que exógenos.

Outro ponto a ressaltar é que o mercado empresarial tende a investir em ações de natureza social ou ambiental devido a atual legislação, mas isso não quer dizer que elas concordem com a lei a elas imposta, apenas a cumprem. Muitas vezes o tipo de negócio de uma empresa é totalmente contrário ao que a legislação permite. Nesse caso, as empresas mascaram suas reais intenções e realizam ações de marketing dizendo-se ecologicamente corretas sem necessariamente o serem. O Conselho Nacional de Autorregulamentação Publicitária (CONAR) chama essa prática de "greenwashing" que se refere ao procedimento de marketing utilizado por uma organização com o objetivo de prover uma imagem ecologicamente responsável dos seus produtos ou serviços sem que o seja na realidade, ou seja, é uma forma de mascarar ação contrária ao apelo ecológico.

A procura dos consumidores por produtos que se apresentam como ecologicamente corretos vem crescendo nos últimos anos, principalmente com o aumento da preocupação do consumidor global em relação às questões e problemas ambientais que tem se agravado com o passar do tempo (tais como a preocupação com o aquecimento global e as consequentes mudanças climáticas, entre outros). [...] O aumento da demanda real e potencial por produtos mais "verdes" tem estimulado muitas empresas a se posicionar favoravelmente como oferta capaz de preencher esta procura, algumas de forma genuína, congruente e transparente. No ano passado, anúncios sobre Responsabilidade Social Empresarial e Sustentabilidade Corporativa ganharam ainda mais força entre mídias impressas, totalizando o maior número de anúncios desta natureza desde o ano de 2003 (CONAR, 2014). 
A publicidade deve ser ética e responsável já que é uma ferramenta importante no processo de construção das marcas e da própria sociedade. De acordo com uma pesquisa realizada pelo Instituto de Pesquisas Market Analysis (2014, p. 14-15), o Brasil é o país que menos pratica greenwashing, ficando em quinta posição em relação aos Estados Unidos, que lidera o ranking, seguidos por Canadá, Austrália e Reino Unido. A pesquisa apresentou dados de que os produtos brasileiros são os que usam menos apelos em suas embalagens para dar ao consumidor uma falsa impressão de preocupação ambiental. Ainda assim, a prática é frequente no país: 90\% de todos os produtos nacionais, analisados pela pesquisa, possuem algum tipo de apelo ecológico. Demonstrando, portanto, que o apelo ecológico é também um forte argumento de venda de produtos.

Essa situação também mostra que o mundo inteiro está preocupado com o impacto ambiental no consumo de seus produtos. A mídia foca no consumo consciente, a legislação se torna mais dura para as organizações e, para se manterem no mercado, algumas empresas divulgam campanhas de responsabilidade social e de sustentabilidade ambiental no intuito de passar uma imagem ecologicamente correta que não condiz com a sua realidade de atuação. Entretanto, essa atitude empresarial mascarada acaba por prejudicar o meio ambiente, deixando o ser humano fragilizado frente a um futuro incerto da própria sobrevivência.

\section{OS ANÚNCIOS PUBLICITÁRIOS SUSTENTÁVEIS}

Um anúncio publicitário é aquele que busca persuadir o consumidor (receptor), convencendo-o sobre a qualidade de um produto, fazendo-o adquiri-lo. Para aumentar o grau de aceitação, os anúncios publicitários são objetivos e também criativos, deixando evidente o conhecimento que tem sobre seu público-alvo Geralmente são utilizados no contexto de uma campanha publicitária. Esta é utilizada pelo conjunto de anúncios criados dentro de um único planejamento ou ideia conceitual para uma determinada marca. Tudo é planejado, criado estrategicamente para que, dessa forma, causem sinergia entre eles e ampliem o impacto da campanha positivamente (PÚBIO, 2008).

Assim sendo, uma campanha publicitária é um conjunto de peças que são criadas no intuito de atingir um determinado público-alvo, expondo e fixando uma mensagem da marca e também abordando um diferencial 
ou apelo (racional ou emocional) do produto. Cada peça tem autonomia no processo de comunicação, ou seja, contempla passar uma mensagem completa. Utiliza-se de uma linguagem verbal' composta por:

a) Título e subtítulo, geralmente criativos e atraentes no jogo das palavras, dando sentido duplo ao mesmo. Utilizando linguagem conotativa para deixar o anúncio mais atrativo.

b) Corpo do texto ou texto informativo - aqui se desenvolve com maior persuasão o conceito do título. Usa-se frases curtas, objetivos e imperativas, adaptando as palavras ao cotidiano do público-alvo. Nome do próprio empreendimento que dá duplo sentido ao material.

c) Nesta parte é desenvolvida a ideia sugerida no título, com frases curtas, claras e objetivas, adequando o vocabulário aos interlocutores destinados.

Os anúncios também são compostos por uma linguagem visual que como o nome já diz tem a ver com o conjunto de imagens utilizadas no material publicitário. Sendo assim é composta de: Imagens - são escolhidas as que mais chamam a atenção do público-alvo de acordo com as características do produto anunciado; cores utilizadas no anúncio e a forma como o anúncio foi escrito e idealizado. O que caracterizaria um anúncio publicitário sustentável é o fato de ele utilizar algum argumento de sustentabilidade em seu contexto e não necessariamente de ele ser sustentável em si. Nesse sentido, torna-se importante ressaltar alguns conceitos empresariais utilizados neste artigo, como o das construtoras e incorporadoras, ou seja, empresas voltadas para o setor da habitação. Atuam na construção de prédios, casas, condomínios e projetam loteamentos.

Um loteamento é a divisão de uma grande área de terra em lotes menores destinados à edificação. O responsável é o loteador, que pode ser tanto uma pessoa física, como uma empresa privada, um órgão público ou uma cooperativa. Qualquer que

1 O slogan da marca também é uma linguagem verbal, contudo, não será objeto de análise neste estudo.

Rev.Cad. Comun. Santa Maria, v.21, n.1, art 3, p.72 de 85, jan/abr.2017 
seja o loteador, as vendas dos terrenos só poderão ocorrer após a aprovação de um projeto na prefeitura (PREFEITURA DE PORTO ALEGRE, 2013).

Portanto, para que uma área seja loteada, primeiramente, é necessária a aprovação do projeto pela prefeitura, que irá definir, inclusive, quanto de espaço verde o loteamento deverá possuir. Este espaço verde é determinado por lei municipal, logo, é obrigatório e calculado de acordo com o tamanho do loteamento, sendo este para uso público. De acordo com Abreu e Oliveira (2004) "a exigência de espaços livres de uso público, além de compensar a degradação, [...] agrega valor ao produto, que, no caso, são os lotes urbanizados [...]." É uma forma de promover a valorização do imóvel, já que a sociedade incorporou esse valor de qualidade de vida ambientalmente mais saudável. A exigência das áreas verdes é mais do que um elemento urbanístico. Tem a ver, segundo os autores, com "a necessidade higiênica, de recreação e até defesa e recuperação do meio ambiente em face da degradação de agentes poluidores". Entretanto, reservar um espaço dessa natureza não é uma iniciativa que parte dos loteadores, mas é uma decorrência das exigências legais que determinam a existência dessas áreas verdes.

As empresas transformam as leis ambientais impostas a elas e as utilizam como argumentos de venda de seus produtos, tendo os recursos da publicidade como um grande aliado de seus negócios. Na área da construção civil, percebe-se muito esse apelo à sustentabilidade ambiental nos anúncios publicitários, mais especificamente nas propagandas referentes a condomínios, residenciais ou loteamentos. É comum o emprego de expressões relacionadas com a natureza dentro de um discurso peculiar nesses anúncios. Quase todas as campanhas se utilizam dos mesmos argumentos, variando em um ou outro aspecto. Umas focam na área verde que deixa o loteamento mais urbanizado, outras direcionam o olhar para as árvores plantadas obrigatoriamente ao longo de uma rua ou uma lagoa que obrigatoriamente teve que ser preservada e mantida no empreendimento. Enfim, a intenção da propaganda não é associar a obra somente ao aspecto paisagístico, mas também, indireta ou diretamente, à sustentabilidade ambiental sem necessariamente apresentá-la como um produto ecologicamente correto. Essa informação ficaria subentendida no discurso publicitário. Contudo, o campo da construção civil é extremamente competitivo e qualquer argumento de venda pode ser decisivamente van-

Rev.Cad. Comun. Santa Maria, v.21, n.1, art 3, p.73 de 85, jan/abr.2017 
tajoso para a empresa.

\subsection{OS ANÚNCIOS PUBLICITÁRIOS NA PERSPECTIVA DA SUSTEN- TABILIDADE AMBIENTAL}

Os anúncios publicitários analisados corroboram com a discussão deste estudo à luz da linguagem publicitária (linguagem verbal e não verbal). Salienta-se que os mesmos serão analisados a partir do nome do empreendimento facilitando o diagnóstico deste estudo. Sendo assim, os anúncios do Residencial Portal das Águas, do Reserva do Bosque, do Residencial Bosque Pau Brasil, do Residencial Vila do Verde, do Reserva Bacutia, do Ponta Negra Beach utilizam já no nome do empreendimento um certo apelo publicitário remetendo à ideia de sustentabilidade ambiental. O nome do empreendimento é definido a partir do conhecimento do público-alvo, podendo inclusive também remeter, a partir do nome, à classe social de seus futuros compradores, eletizando ou não um empreendimento.

De forma geral, os loteamentos comercializados pelas construtoras, incorporadoras e imobiliárias (e também os próprios anúncios institucionais dessas empresas) do setor de construção civil utilizam dos seguintes argumentos verbais e racionais em seus anúncios: $n^{\circ}$ de lotes para venda a partir de uma metragem quadrada mínima, metragem quadrada de área verde, asfalto e meio-fio; iluminação pública; rede de água tratada; rede de energia elétrica; acesso fácil, e também outros de apelo emocional como: proximidade à natureza, nome do empreendimento atrelado a um apelo sustentável, paisagem em volta do imóvel, entre outros.

Percebe-se que os textos publicitários que utilizam destas estratégias se posicionam sutilmente como sendo sustentáveis ambientalmente. Possuir mais de $100 \mathrm{mil} \mathrm{m}^{2}$ de área verde e ainda uma reserva ecológica (FIGURA 1) ou se auto intitular como um Residencial ecologicamente correto (FIGURA 2) é uma condição que situa explicitamente os anúncios publicitários dos empreendimentos analisados como empreendimentos voltados às ações sustentáveis para o planeta, mesmo que estas não o sejam.

Portanto, neste posicionamento já se tornam competitivos mercadologicamente. Contudo, algumas questões devem ser discutidas: como um empreendimento oferece uma reserva ecológica privada ou o que faz um empreendimento ser ecologicamente sustentável? Ações superficiais ou de economia para o próprio empreendimento já o tornariam sustentável

Rev.Cad. Comun. Santa Maria, v.21, n.1, art 3, p.74 de 85, jan/abr.2017 
ambientalmente? Se faz necessário compreender o contexto da sustentabilidade ambiental e tudo o que ele agrega para que se possa afirmar e manter o discurso ecológico.

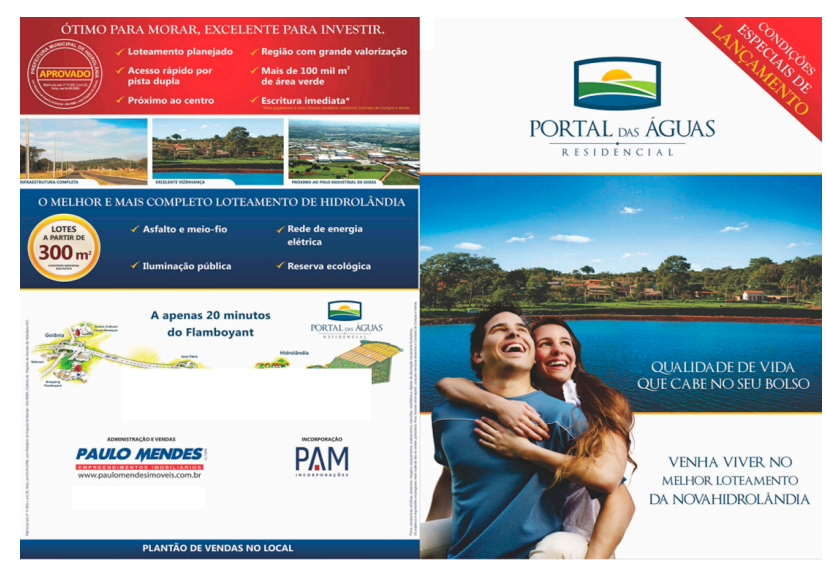

Figura 1 - Anúncio publicitário do Portal das Águas (folder institucional)

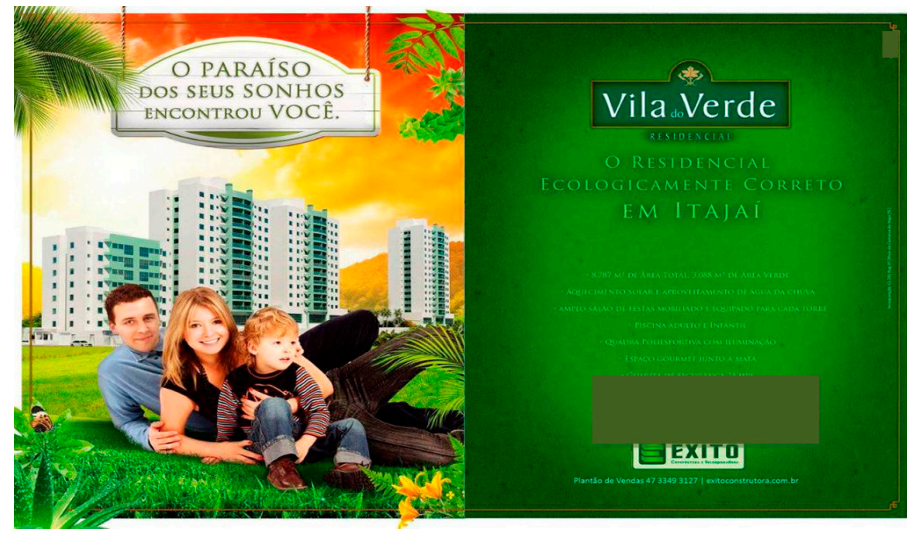

Figura 2 - Vila do Verde Residencial

De acordo com Fornari Neto (2001, p. 217) uma reserva ecológica ou reserva biológica ou reserva natural é uma área de maior ou menor extensão, para proteger integralmente a flora e a fauna no seu conjunto, ou uma espécie em particular, com objetivos educacionais e científicos. Portanto, as reservas ecológicas ou bosques, divulgados nos anúncios analisados neste artigo, devem estar situados ao lado dos loteamentos ou residenciais e não ter sido criados em razão deles. Não deixa transparente ao consumidor se trata-se de um argumento de venda de uma empresa sustentável ambientalmente ou de um apelo para a sustentabilidade do negócio da própria empresa. Outros anúncios também utilizam a mesma estratégia, porém de outra forma: utilizam o nome do empreendimento diretamente associado a uma reserva ecológica como o Reserva Bacutia (FIGURA 3) e Ponta Negra Beach (FIGURA 4). Contudo, a conexão entre 
sustentabilidade e empreendimento pode ser feita indiretamente também, apenas na sutileza dos textos informativos ou subtítulos.

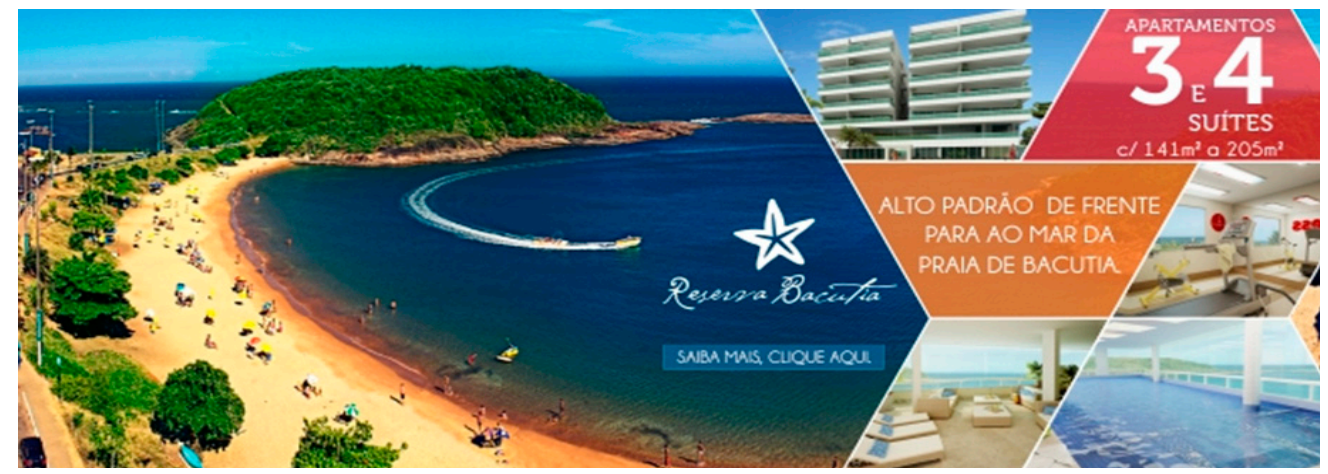

Figura 3 - Reserva Bacutia

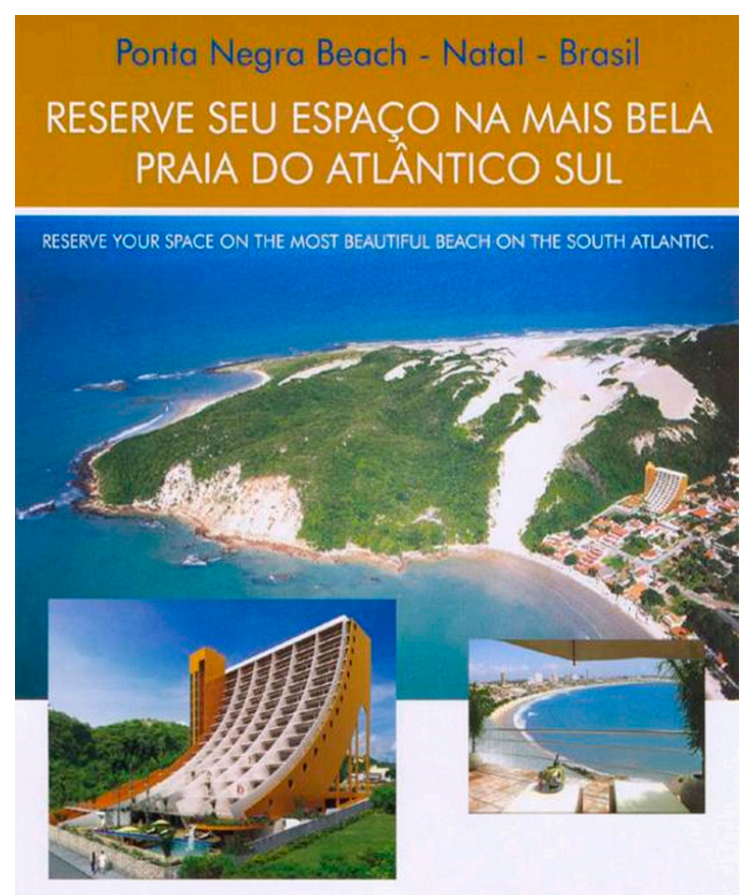

Figura 4 - Ponta Negra Beach

Em uma das chamadas do Artemis Residencial (FIGURA 5) há um apelo publicitário aos “Aptos. com sol da manhã”, provavelmente fazendo menção à localização do prédio de que o mesmo é iluminado em certo horário do dia e não durante o dia todo (também não deixando claro o que seria apartamento com o sol da manhã).= 


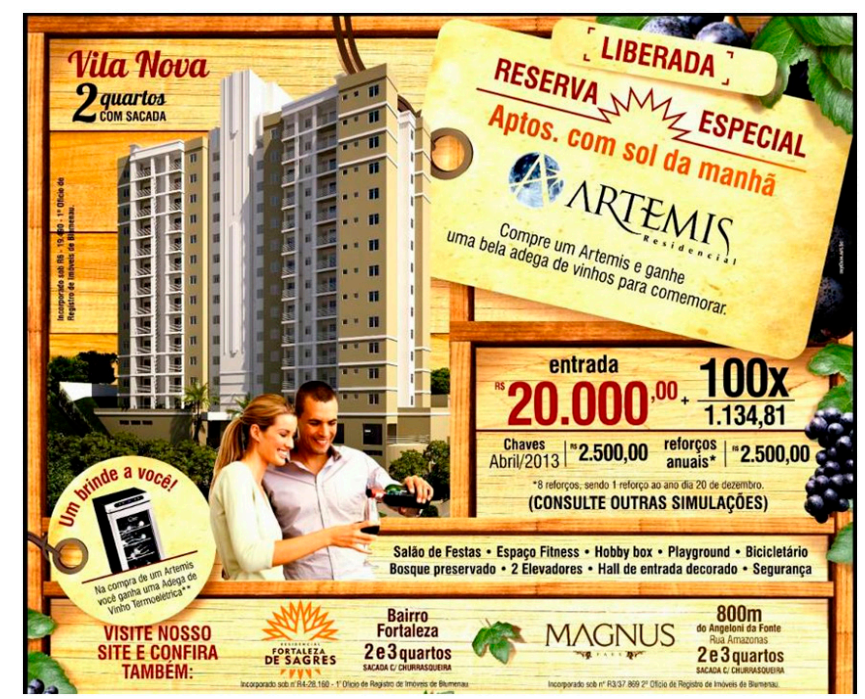

Figura 5 - Artemis Residencial

O Artemis também menciona também que tem um bosque preservado, não definindo o tamanho da área verde ou se o mesmo está ou não integrado ao empreendimento, deixando essa informação subentendida na peça publicitária. No anúncio do Ponta Negra Beach (FIGURA 4) se tem a impressão de que o empreendimento é um praia inteira. Não qualquer praia, mas a mais bela do Atlântico Sul. O que se questiona é se pode ou não comercializar uma praia segundo as leis brasileiras. E o Reserva do Bosque (FIGURA 6) que afirma que 70\% do empreendimento é um bosque preservado, levando a crer, já que não deixa essa informação clara, de que o comprador, além do imóvel ou lote a ser adquirido, também seria o dono de um bosque.

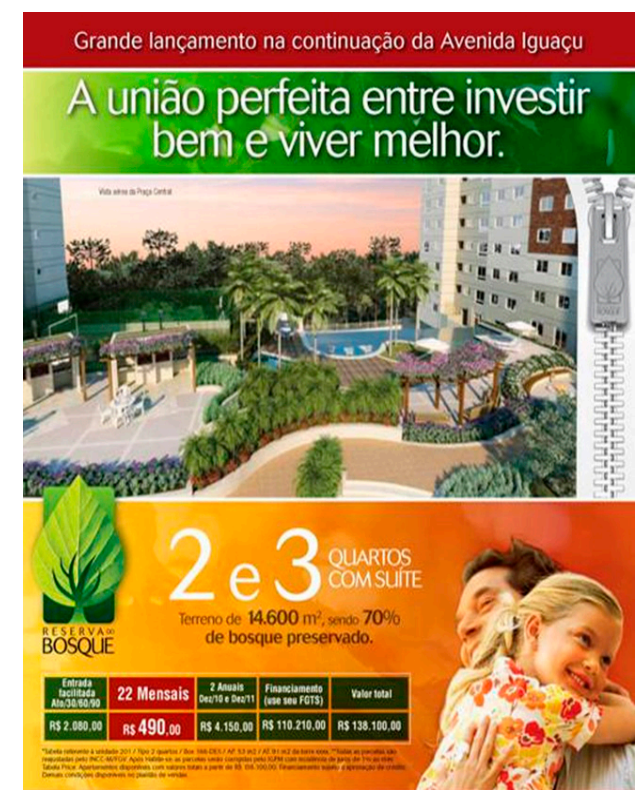

Figura 6 - Reserva do Bosque

Rev.Cad. Comun. Santa Maria, v.21, n.1, art 3, p.77 de 85, jan/abr.2017 
Ao citar propositalmente a expressão "reserva ecológica" ou "área verde com mais de 100 mil m", como o caso do Portal das Águas (FIGURA 1), a propaganda já faz uma referência sutil ao tipo de consumidor deste empreendimento. O preço é outro elemento que se refere também ao público-alvo, Contudo, o atributo emocional tem um apelo maior. $\mathrm{O}$ anúncio é uma espécie de mediação entre empresa e consumidor. Casaqui (2009) diz que essa negociação mediada pela publicidade traz elementos simbólicos para a realidade das pessoas. Sendo assim, ter uma reserva ecológica ou um bosque preservado é praticamente o mesmo que morar ao lado de uma, dentro de um contexto simbólico. Entretanto, são duas coisas bem diferentes. O fato de o loteamento ter uma área verde tão grande assim, isso se deve às leis ambientais e municipais que assim determinaram, portanto, a proposta não partiu da iniciativa da empresa. Mesmo assim, ela se utiliza desse argumento em benefício do próprio negócio ou de um produto mercadológico com outra conotação.

Questões como ter áreas verdes (o que é uma lei municipal), aquecimento solar e aproveitamento da água da chuva (fatores que trazem também economia ao empreendimento) seriam o suficiente para caracterizar um empreendimento como "ecologicamente sustentável", como no caso do Vila do Verde Residencial (FIGURA 2). Nesse contexto, o anúncio institucional da construtora Tabaporã (FIGURA 9) também utiliza em sua chamada principal a seguinte afirmação: "Construtora Tababorã, contribuindo com o crescimento sustentável de Caraguatatuba", porém não deixa claro de que forma ela contribui com esse "crescimento sustentável". Todos os anúncios acabam ligando o argumento de garantia da qualidade indiretamente ao crescimento sustentável ou ecologicamente correto. Nas imagens abaixo dos textos, que deveriam evidenciar o crescimento sustentável, aparece a foto de uma praia e logo abaixo fotos de prédios construídos sem nenhum apelo sustentável. Fica embutida na linguagem verbal e na visual que se trata de sustentabilidade ambiental, porém as imagens e o texto não reafirmam este posicionamento da construtora. 


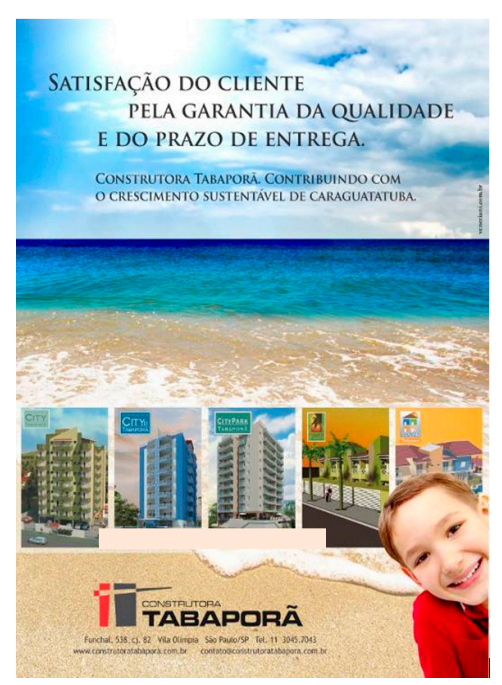

Figura 7 - Anúncio institucional Construtora Tabaporã

O discurso publicitário, conforme relembra Randazzo (1997) e Baudrillard (2008), cria todo um cenário que busca persuadir e envolver o consumidor. É o papel de espelho que, segundo Marcondes (20002), a publicidade tem perante a sociedade de consumo. Nesse caso, a sustentabilidade deixa de ser uma prática e passa a ser um produto de consumo.

O layout do anúncio do Portal das Águas, por exemplo, tem em seu título um argumento misto (FIGURA 1), baseado em elementos emocionais (qualidade de vida) e racionais (cabe no seu bolso). $O$ apelo racional não faz necessariamente referência ao preço acessível, mas ao valor da qualidade de viver bem de quem está lendo o anúncio. E conta com um texto auxiliar que faz um convite imperativo (venha viver) específico (no melhor loteamento). O uso de adjetivos enaltecendo o produto são artifícios muito usados nos textos publicitários (o melhor loteamento, ótimo para morar, excelente para investir, o melhor e mais completo loteamento, a apenas 20 minutos, excelente vizinhança). As imagens (linguagem não verbal) estão em sintonia planejada com o texto: um casal feliz, um lindo céu azul, uma lagoa preservada, muitas áreas verdes. A predominância da cor azul remetendo à credibilidade e seriedade, assim com o vermelho ligando à emoção. E finalizando com o branco, transparência. O próprio nome do loteamento reflete algo simbólico dentro do conceito ambientalmente correto. $O$ texto (linguagem verbal) tem uma forte capacidade de persuasão e convencimento, conforme ressaltado por Muniz (2005). Entretanto, ele é um texto pré-definido com imagens escolhidas especificamente para reforçar o discurso do material publicitário do empreendimento. 
Estes sãos alguns exemplos de textos de anúncios publicitários que colocam a sustentabilidade ambiental como um produto mercadológico. Há ainda a linguagem visual que em todos os anúncios analisados que fazem referência a paisagens exuberantes como nos materiais do Reserva Bacutia (FIGURA 2), no Ponta Negra Beach (FIGURA 4) e no Portal das Águas (FIGURA 1). Praticamente todos utilizam as cores dourado (amarelo ouro), azul e verde em maior evidência em seus layouts. Estas cores fazem referência à valorização do empreendimento, sua credibilidade e associação com a natureza, deixando a imagem ou cores ocupar maior parte do anúncio, visto que seriam esses os argumentos de venda mais relevantes. Têm apelo emocional e foco na sustentabilidade ambiental, na tentativa de tocar o consumidor recorrendo para a sua consciência no cuidado com o meio ambiente e dessa forma, concretizar a venda de um produto mercadológico. Ou o apelo pode ainda ser em mostrar árvores ou algo que remeta à natureza e que esteja próximo ao empreendimento, como o Reserva do Bosque (FIGURA 6), no qual aparece parte do mencionado bosque, porém cercado; e o paisagismo de um dos ambientes externos do empreendimento.

O Artemis Residencial (FIGURA 5), por exemplo, utiliza o mínimo de natureza aparecendo em seus anúncios, mesmo assim acaba remetendo sutilmente à ideia de natureza. Até mesmo o Residencial Bosque Pau Brasil (FIGURA 8), que leva em seu nome a expressão "bosque" possui o mínimo de elementos da natureza em sua composição publicitária.

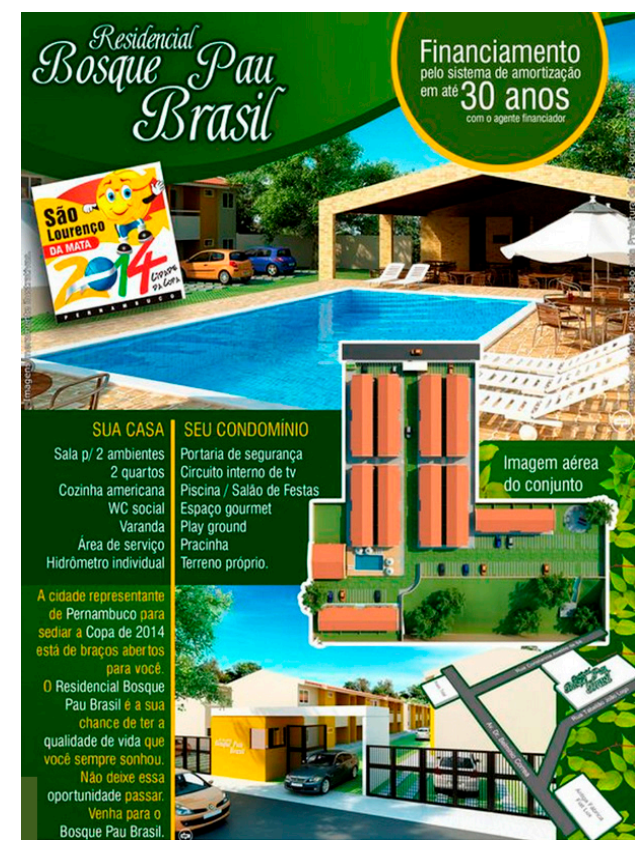

Figura 8 - Residencial Bosque do Pau Brasil

Rev.Cad. Comun. Santa Maria, v.21, n.1, art 3, p.80 de 85, jan/abr.2017 
Já os anúncios do Reserva Bacutia (FIGURA 2) e do Ponta Negra Beach (FIGURA 4) utilizam imagens que mostram a amplitude da natureza, não deixando claro onde começaria e nem onde seria o limite destes empreendimentos, assim como o Portal das Águas (FIGURA 10) conforme aparece no mapeamento de seus lotes.

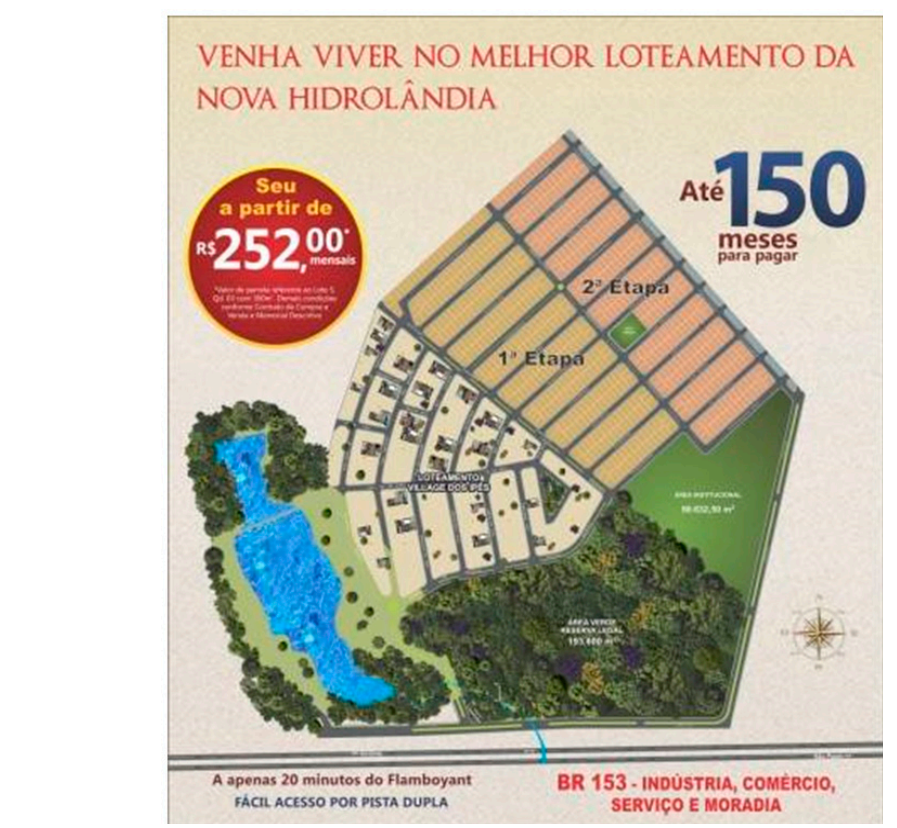

Figura 9 - Residencial Portal das Águas - planta visual do loteamento

Portanto, fica implícito nestes materiais publicitários que eles contemplam toda a área das fotos que consta em suas peças gráficas, associando-os, dentro de uma linguagem não verbal, à sustentabilidade ambiental. $\mathrm{E}$, dessa forma, os coloca em um grau de competitividade muito maior do que os outros. Sendo também, uma publicidade dúbia, ou seja, nem verdadeira nem falsa, pois o comprador só tomará conhecimento dos detalhes do empreendimento se for buscar informações com os corretores desses empreendimentos. Contudo, segundo o CONAR (2014), um anúncio não pode induzir ao erro ou inserir informações que levem o consumidor ao erro. Uma linguagem não verbal, feita através de fotos panorâmicas, que não deixam expostas os objetivos de um anúncio publicitário, pode levar o consumidor a adquirir um produto (imóvel ou lote) que não oferece na realidade os atributos anunciados. Quando se vende a ideia de uma vista junto à natureza, por exemplo, no meio de uma cidade, deve-se levar em conta que se o vizinho construir um prédio maior, a vista panorâmica que o consumidor "comprou” junto com o imóvel ou lote, será apenas argumento de venda e não mais um atributo verdadeiro do anúncio feito ante- 
riormente na ocasião da compra do imóvel.

\section{CONSIDERAÇÕES}

O estudo aqui apresentado debateu o uso da linguagem publicitária, verbal e não verba, na perspectiva da sustentabilidade ambiental, através da análise de anúncios publicitários das construtoras, incorporadoras e imobiliárias brasileiras. Buscou levantar questionamentos sobre a utilização desta publicidade como ferramenta no processo de construção da imagem socioambiental e sustentável de uma empresa e suas marcas de produtos (os empreendimentos), trazendo a reflexão do poder do discurso publicitário permeado por simbolismos e metáforas. A publicidade deve ser ética e responsável durante todo o seu processo, não induzindo o consumidor ao erro. É preciso deixar claro os atributos reais de um produto (sejam eles racionais ou emocionais), não os mascarando (como na prática do greenwhasing).

As palavras quando utilizam a linguagem publicitária, com imagens simbólicas e metáforas que têm sintonia com um discurso também publicitário, criam um cenário persuasivo propício para o envolvimento do consumidor. E, portanto, se tornam importantes argumentos competitivos. Tudo é focado para que as pessoas ajam de acordo com um comportamento pré-estipulado, planejado estrategicamente. Embora seja importante às empresas terem suas vantagens competitivas evidenciadas, não se pode utilizar o contexto da sustentabilidade ambiental apenas como apelo mercadológico sem levar em conta o complexo e incerto cenário futuro. Consequentemente, deve haver uma maior responsabilidade das empresas (de todos os setores) quando criam seus anúncios publicitários com foco na sustentabilidade ambiental. A sociedade precisa refletir sobre a forma com que a publicidade tem sido utilizada pelas organizações e também sobre seu papel na sociedade contemporânea, assim como, sua presença na complexidade do cenário do desenvolvimento, seja ele local, regional ou nacional. 


\section{REFERÊNCIAS}

ABREU, A. H; OLIVEIRA, R. J. Áreas verdes e municípios. 2004. Disponível em < http://portal.mp.sc.gov.br/portal/conteudo/cao/cme/areas_verdes_e_municipios_ cme.pdf>. Acesso em: 03 jan. 2014.

BACHA, Maria de Lourdes ; SCHAUN, Angela. Considerações teóricas sobre o conceito de sustentabilidade: uma reflexão sobre elementos conceituais e revisão de literatura. In: SCHAUN, Angela; UTSUNOMIYA, Fred (Org.). Comunicação e sustentabilidade: conceitos, contextos e experiências. Rio de Janeiro: E-papers, 2010, p. 11-36.

BAUDRILLARD, Jean. O sistema dos objetos. São Paulo: Perspectiva, 2008.

BEMFICA, G. Couto; BEMFICA, J. Couto. A Comple(xC)idade: Natureza, Economia, Política e Sociedade. Disponível em: <http://revistapensar.com.br/engenharia/pasta_upload/artigos/a103.pdf>. Acesso em: 18 dez. 2014.

CASAQUI, Vander. Processos de representação e referencialidade na publicidade contemporânea: mundo do trabalho, cidade, beleza e ativismo social. Revista Eletrônica Signos de Consumo (USP), Janeiro-Junho/ 2009. Disponível em: http://www.usp.br/ signosdoconsumo/edo02/artigos/RSC_02_VanderCasaqui.pdf. Acesso em: 24 jan. 2014.

CONAR. Conselho Nacional de Autorregulamentação Publicitária. Site institucional. Greenwashing no Brasil: Um estudo sobre os apelos ambientais nós rótulos dos produtos. Disponível em: <http://www.marketanalysis.com.br/biblioteca/Relatorio_Greenwashing_FINAL.pdf>. Acesso em: 13 jan. 2014.

FORNARI NETO, Ernani. Dicionário prático de ecologia. São Paulo: Aquariana, 2001.

JONES. John Philip (org). A publicidade na construção de grandes marcas. São Paulo: Nobel, 2004.

KATO, Cristiano Arns. Arquitetura e sustentabilidade: projetar com ciência da energia. Dissertação de mestrado. Arquitetura e Urbanismo. Universidade Presbiteriana Mackenzie, 2007. Disponível em < http://ambientalistasemrede.org/wp-content/uploads/2013/05/cp067250.pdf>. Acesso em: 5 jan. 2015.

MARCONDES, Pyr. Uma história da propaganda brasileira. Rio de Janeiro: Ediouro, 2002.

MARKET ANALYSIS. Instituto privado de pesquisas em estudos sobre o mercado e a opinião pública. Site institucional desde 1997. Disponível em < http://marketanalysis. com.br/wp-content/uploads/2014/07/Greenwashing-in-Brazil.pdf>. Acesso em: 10 jan. 2014 . 
CADERNOS DE COMUNICAÇÃO

UNIVERSIDADE FEDERAL DE SANTA MARIA

MUNIZ, Eloá. Comunicação publicitária em tempos de globalização. Canoas: Ed. ULBRA, 2005.

NEOMUNDO. Instituto Neo Mundo divulga, informa, debate e fomenta ações que contribuem para um novo modelo de gestão e práticas sociais no mundo corporativo e na sociedade, alicerçadas na sustentabilidade e no desenvolvimento de forma ética e responsável. Disponível em <http://www.neomondo.org.br/images/stories/pdf_revista/ed7.pdf>. Acesso em: 23 jan. 2014.

PREFEITURA DE PORTO ALEGRE. Site Institucional. Disponível em < http://www2.portoalegre.rs.gov.br/pgm/default.php?reg=6\&p_secao=29>. Acesso em 20 dez. 2013.

PNUD. Programa das Nações Unidas para o Desenvolvimento. Relatório de Desenvolvimento Humano. Disponível em < http://hdr.undp.org/en/reports/global/hdr2011 download/pt>. Acesso em: 24 jan. 2014.

RANDAZZO, Sal. A criação de mitos na publicidade: como os publicitários usam o poder do mito e do simbolismo para criar marcas de sucesso. Rio de Janeiro: Rocco, 1997.

REVISTA NEOMONDO. Fevereiro de 2008. Ed. 07, p. 04-05. Disponível em <http:// www. neomondo.org.br/images/stories/pdf_revista/ed7.pdf> Acesso em: 25 jan. 2014.

RIO+20. Conferência das Nações Unidas sobre o Desenvolvimento Sustentável. Disponível em <www.rio20.info> Jun 2012. Acesso em: 24 jan. 2014.

ROSA, Altair. Rede de governança ambiental na cidade de Curitiba e o papel das tecnologias de informação e comunicação. Dissertação de mestrado. Gestão Urbana. Pontifícia Universidade Católica do Paraná, 2007. Disponível em < http://livros01.livrosgratis.com.br/cp029091.pdf>. Acesso em: 27 dez. 2014.

SEN, Amartya. Desenvolvimento como liberdade. São Paulo: Companhia das Letras, 2010.

SOUZA, C. L.; AWAD, J. C. M. Cidades sustentáveis, cidades inteligentes: desenvolvimento sustentável num planeta urbano. Porto Alegre: Bookman, 2012.

Rev.Cad. Comun. Santa Maria, v.21, n.1, art 3, p.84 de 85, jan/abr.2017 


\section{Giovana Goretti Feijó de Almeida}

Doutoranda e Mestre em Desenvolvimento Regional (UNISC). Especialista em Branding e Bacharel em Comunicação Social/Publicidade e Propaganda (UNISC). Pesquisadora-membro do Observatório de Desenvolvimento Regional - OBSERVA-DR. E-mail: goretti.giovana@gmail.com

RECEBIDO EM: $12 / 03 / 2016$

ACEITO PARA PUBLICAÇÃO: 12/05/2016 